Uşak Üniversitesi Sosyal Bilimler Dergisi

$2015,8 / 2$

\title{
XIX. ve XX. Yüzyılda Bazı Seyyahların Kırgızların Dinî Hayatlarına Dair Gözlem ve Değerlendirmeleri
}

\section{Öz}

Cihad CiHAN ${ }^{*}$

Türk halklarının İslamlaşması şehirliler ve konar-göçerler olarak iki temel sosyo-kültürel farklılığa göre gerçekleşmiştir. Türk halklarının büyük bir kısmı VIII-XIII. yüzyıllarda İslamlaşma sürecini önemli ölçüde tamamlamıştır. Ancak Kazak ve Kırgızlar gibi konar-göçer Türk halklarının İslamlaşması daha sonraki yüzyıllara sarkmıştır. Kırgız boylarının nerede, ne zaman ve nasıl Müslüman oldukları kesin bilgiler ile ortaya konulamamaktadır. Bu sebeple Kırgız boylarının İslamlaşma şekli ve düzeyi de tartışmalı bir konudur. Bu konuda XIX. ve XX. yüzyıl seyahatnamelerinin bazılarında çeşitli gözlem ve değerlendirmeler bulunmaktadır. Bu kaynaklarda Kırgızların büyük çoğunluğunun İslam'ı yüzeysel olarak benimsedikleri, eski inançlarını çoğunlukla sürdürdükleri ileri sürülmektedir.

Anahtar Kelimeler: Kırgız, Din, Seyyah, Seyahatname.

\section{9th and 20th Century, Some of the Travelers Observation and} Assessment about the Religious Life of the Kyrgyz

\section{Abstract}

Islamization of Turkish people was realized on the basis of two socio-cultural differences. These differences are nomadic and urban life style. A large part of the Turkish people has completed the Islamization process significantly in the VIII-XIIIth centuries. But Islamization of Turkish nomadic peoples such as the Kyrgyz and Kazakh extended to the next centuries. Questions of when, where and how on the Islamization of the Kyrgyz tribes couldn't revealed exactly. Because of this form and level of the Islamization of Kyrgyz tribes is also controversial issue. In some of travelogues 19th and 20th century in this respect, there are various observations and evaluations. In these sources it has been put forward that the majority of the Kyrgyz adopted the Islam superficially and mostly continued their old beliefs.

Key Words: Kyrgyz, Religion, Traveler, Travelogue.

*Yrd. Doç. Dr., Afyon Kocatepe Üniversitesi, Fen-Edebiyat Fakültesi, Tarih Bölümü 


\section{Giriş}

Kırgızların dinî hayatı, başta Seyfettin Erşahin olmak üzere Mustafa Erdem ve Kemal Polat gibi bir kısım akademisyenlerce araştırılmış, bu konuda kıymetli yayınlar yapılmıştır. Bunların yanı sıra çeşitli tezler hazırlanmış, bazı makaleler de yayınlanmıştır. Bu çalışmalarda diğer kaynaklarla birlikte, genellikle Rus seyyahların eserlerinden istifade edilmiş, ancak aynı döneme ait bazı batılı seyyahların eserlerindeki bilgiler genellikle kullanılmamıştır. Yine bu konu ele alınırken yöntem olarak, diğer Türk halklarında olduğu gibi, Kırgızların dinî tarihini de Türk dinî tarihi içinde değerlendirmek gerekmektedir. Türk halklarının dinî hayatı üzerinde yapılan çalışmalarda Türklerin İslam'ı benimsemesinde ortaya çıan yerleşik ve konar-göçer farklılığı daima göz önünde tutulmalıdır.

Türk halklarının İslam'ı benimsemesi ve kültürlerine adapte etmeleri farklı şekillerde ve zamanlarda tezahür etmiştir. İslamiyet VIII-X. yüzyılda Türkistan'ın çeşitli bölgelerindeki Türk halkları arasına girmeye başladığı zaman, birbirinden farklı iki sosyo-kültürel ortama göre nitelik kazanmıştır. Yani Türk tarihinde İslam dini, sosyal yaşantı ve kültür temelinde iki değişik görünüm sergilemektedir:

Bunlardan birincisi yerleşik, şehirli Türklerdir. Şehirli ahali belirli bir yerde meskûn olması sebebiyle, medreselerde işlenen ve öğretilen, tabiatıyla İslam'ın kitabi esaslarına daha sadık olan, aynı zamanda gelişmiş ve rafine bir kültür, sanat ortaya koymuş, çoğunlukla Sünni Müslümanlığı benimsemiştir.

İkincisi ise bozkırda yaşayan konar-göçer Türklerdir. Bu Türklerde ise sosyolog ve antropologların "popüler İslam" veya "halk İslam'ı" dedikleri, kısmen mitolojik inanç ve kültlerle karışık, popüler bir sanat ve kültür ortaya koyan İslam anlayışı görülmektedir. Konar-göçer Türkler, eski inançlarının etkisinde kalan, biraz da tasavvuf ağırlıklı bir mistik Müslümanlık anlayışını benimsemişlerdir. Bu halk İslam'ının da Türkler arasında iki biçimi bulunmaktadır. Birincisi ortodoks da denilen Sünni yorumu benimsemiş halk kesiminin sergilediği biçim, ikincisi ise heteredoks da denilen Bâtıni anlayış biçimidir. Ancak her ikisi de aynı tabana dayanır; bu ortak taban halk İslam'ıdır (Ocak, 2002: 15-16; 2011: 45).

Tarihi kaynaklarda Kırgızların hangi boylarının ne zaman, nerede ve nasıl İslamlaştı̆̆ yönünde yeterli bilgi bulunmamaktadır. Kaynaklarda Kırgızların İslamlaşma süreci uzun bir zaman aralığında, genel olarak Karahanlılar (840-1212), Çağataylar (XIII-XVII. yüzyıllar) ve Hokand Hanlığ (1740-1876) dönemlerinde ele alınmaktadır. 
XIX. yüzyılda Kırgız boyları Issık göl, Tanrı dağları, Talas, Fergana, Yedi Su, Pamir gibi geniş bir alana dağılmış vaziyetteydiler. Günümüzde Kırgızistan'ın merkezinde bulunduğu bu Kırgız yurdunun dağlık coğrafyası kuzey ve güney bölgeleri arasına doğal bir sınır çizmiştir. Kırgızistan coğrafyasında Çuy (Tokmak), Talas, Issık göl ve Narın kuzey bölgelerini; Oş, Celal-Abad ve Batken de güney bölgelerini oluşturmaktadır. Kırgız yurdunun iki bölgeye ayrılmasında hem tarihi hem de coğrafi sebepler yatmaktadır. Bu bölgesel farklılık dinî hayata da tesir etmiştir. Kırgızların İslamlaşmasında çok az oranda şehirli İslam etkisi özellikle güney bölgelerinde görülmektedir. Tanrı dağları çevresi, kuzey bölgeleri ve Pamir bölgesi gibi konar-göçer hayatın XX. yüzyılın başlarına kadar sürdüğü yurtlarda ise halk İslam'ının ismen Sünni olmakla birlikte eski inançların ve geleneklerin çok canlı kaldığı heteredoks özellikleri görülmektedir.

\section{Kırgızlar Arasında İslamiyet'in Yayılması}

Kırgızların dinî tarihi genel olarak Türk dinî tarihi içinde ele alınmalıdır. Türklerin İslam dinini benimsemelerinden önce, kısmen de olsa Budizm, Hinduizm, Maniheizm, Musevilik ve Hiristiyanlık gibi dinlere girdikleri bilinmektedir. Ancak bu din değişimleri kısmi olarak, bazı boyların, geleneksel inançları dışındaki bu dinleri benimsemesi şeklinde gerçekleşmiştir. Türklerin dinî tarihinde kitleler halinde din değişimi sadece İslamiyet'in benimsenmesinde görülmektedir. Türklerin arasında İslamiyet'ten önceki yaygın olan din Gök Tanrı inancının merkezinde yer aldığı, atalar kültü ve tabiat kuvvetlerine saygı (yer-su) inancının da bulunduğu Gök Tanrı dini olmuştur. Bu din ile İslam dini arasında başta tek Tanrı inancı ve Tanrının vasıfları olmak üzere pek çok benzerlik bulunmaktadır. Muhtelif Türk halklarında görüldüğü gibi Kırgız boylarından bazılarının da Maniheizm, Budizm ve Nasturi Hıristiyanlığını kabul ettikleri ileri sürülmektedir. Ancak bu dinlerin Kırgızlar arasında yaygınlık kazandığına dair bilgiler bulunmamaktadır. İslam dinine girmeden önce, diğer Türk halkları gibi, Kırgızlar da eski Türk inançlarına sahiptiler (Polat 2005: 25 vd.; Erşahin, 1999a: 398).

Yerleşik Türk halklarının büyük çoğunluğu, VIII-XIII. yüzyıllarda İslamlaşma sürecini önemli ölçüde tamamlamışlar, ancak Türkistan'da Kazak ve Kırgız gibi göçer Türk halklarında bu süreç daha uzun sürmüş ve sonraki yüzyıllara sarkmıştır. Tarihi kaynaklarda Kırgızların hangi boylarının ne zaman ve nasıl İslamlaştığı yönünde açık ve yeterli bilgi çok azdır. Ancak diğer Türk boylarının İslamlaşması ile kıyaslandığında Kırgızların İslam'ı büyük çoğunlukla benimseyip özümsemelerinin daha geniş bir zaman dilimine (X-XVIII. yüzyıllar) yayıldığı söylenebilir (Erşahin, 
1999a: 393, 405). Kırgızların XVI. yüzyıldan daha önce İslamlaştı̆̆ görüşünün temel iki dayanağı Manas destanı ile Kırgızların yaşadığı coğrafi mekân ve burada gelişen tarihi olaylardır (Erdem, 2005: 180).

Esasen farklı bölgelerde, dağınık bir halde yaşayan göçer bir halkın aynı zamanda, topyekûn din değiştirmesi de beklenemez. Kırgızların İslamiyet'i kabul etme süreci Yenisey bölgesinden İslam inanç ve kültürünün hâkim olduğu güneydeki bölgelere göçleriyle başlamıştır. Bu din değişikliğinin ilk olarak Karahanlılar ve Çağataylar döneminde gerçekleştiği, ancak bütün Kırgızları kapsamadığı, bazı boyların daha sonraki dönemlerde İslamlaştığı kabul edilmektedir. Kırgızların farklı boylarının, farklı coğrafyalarda, farklı düzeylerde; Karahanlılar döneminden Hokand Hanlığı dönemine kadar İslamlaşmalarının sürdüğü tarihi kayıtlarda yer almaktadır (Jusubaliev, 2007: 39 vd.). Bu İslamlaşma sürecinde az oranda şehirli, daha ziyade halk İslamı'nın tesirleri görülmektedir.

Kırgızlar kuzey komşuları olan Kazaklar gibi, farklı zamanlarda, farklı boylar halinde İslamiyet'i benimsemişlerdir. Özellikle Özbek ve Tacik gruplarla iç içe bulundukları Fergana Vadisi civarında ve nispeten kolay ulaşılabilir olan bugünkü Güney Kırgızistan'da yaşayan Kırgız boyları dağlık Kuzey Kırgızistan'daki boylara göre daha erken dönemlerde Sünni İslam ile tanışmışlardır. Kuzey Kırgızistan'daki Kırgızların İslamlaşması XIX. yüzyıla kadar sürmüştür. Dolayısıyla, bu Kırgızların Türkistan'da İslamiyet'i seçen son boylar olduğu iddia edilebilmektedir. Bu nedenle, Kırgızlar Türkistan'daki diğer halklara göre (özellikle Özbekler, Tacikler ve Uygurlar) çoğunlukla İslam öncesi dinî inançlarla karışmış heteredoks bir İslam anlayışını benimsemişlerdir (Bozbey, 2011: 20).

Günümüzde de Kırgız halkı İslami yaşantı bakımından bir bütünlük göstermemektedir. Güney Kırgızistan'ın bir bölümünü oluşturan Fergana vadisindeki Kırgız şehirleri Türkistan'ın önemli İslami kültür merkezlerindendir. Ancak, ülkenin kuzey ve doğu bölgelerinde İslami duyarlılık daha azdır (Erşahin 1999b: 41).

Kırgızların dinî hayatı ile ilgili başta Manas destanı olmak üzere çeşitli kaynaklarda muhtelif bilgiler ve görüşler yer almaktadır. Konar-göçer Türk halklarının kültürlerine dair en önemli kaynaklar onları gözlemleyerek bilgiler veren, değerlendirmeler yapan seyyahların eserleri olmuştur. Yine bu konar-göçer halklar çok cüzi değişiklikler dışında hayat tarzlarını Rusların onları yerleşik hayata zorladıkları XX. yüzyılın başlarına kadar sürdürmüşlerdir. $\mathrm{Bu}$ sebeple $\mathrm{XX}$. yüzyılın başlarına kadar, onların topraklarından geçen seyyahların eserlerindeki bilgilere bakarak bu konargöçer halkların Orta Çă̆'daki atalarının kültürel durumu hakkında dahi 
bağlantılar kurulabilir. Çünkü yerleşik hayata geçişe kadar ciddi kültürel değişimler olmamıştır. XIX-XX. yüzyıl seyyahları çoğunlukla söz konusu Türk halklarının Müslümanlığı ve dindarlık düzeyleri hakkında bazen belirsiz ve şüpheli ifadeler kullanmaktadırlar (Erşahin, 1999a: 398). Kırgızlar arasında gezen seyyahların verdiği bilgilerin bir kısmı da birbiriyle çelişmektedir (Erdem, 2005: 137). Bu durum Türk halklarının İslamlaşma farklılıklarının, özellikle konar-göçer hayatın, eski Türk din ve inançlarının göz önünde bulundurmadan göçer Türk halklarının dinî yapısının değerlendirilmesinden kaynaklanmaktadır. XIX-XX. yüzyıl seyahatnamelerinde ayrıca ön yargılar ve kısa süreli yetersiz gözlemler ile tetkik edilmeden kabul gören nakiller de yer almaktadır. Bu yüzden seyyahların verdiği bilgiler mukayese edilerek, ihtiyatla ele alınmalıdır.

\section{Seyyahların Kırgızların Dinî Hayatlarına Dair Gözlem ve Değerlendirmeleri}

XIX. yüzyılda Kırgızların dinî hayatları hakkında bilgi veren seyyahlar, genellikle Kırgızların İslam dinî ile aralarını mümkün olduğunca uzak ve İslam'ın onlar üzerindeki izlerini olabildiğince zayıf göstermektedirler. Rus kaynaklarının göçebe Türk halklarına ve İslam dinine karşı olumsuz yaklaşımları bilinmektedir. Batılıların ise ne kadar tarafsız olabildikleri bir yana, çoğunlukla karşılaştıkları yerel olayları genelleştirme yoluna giderek Kırgızların dinî hayatlarına dair bilgiler vermektedirler (Erdem, 2005: 137). Bunu yaparken de onların dağınık göçebe hayat şartlarını, dinî eğitim imkânlarından yoksun oluşlarını, geleneklerin bu toplumsal yapıdaki canlılığını göz önünde tutmazlar. Ancak bu konuda bilgi veren, değerlendirme yapan seyyahların tamamı Kırgızların Müslüman olduğu konusunda hemfikirdirler.

Tarihî bilgilere göre Türkistan'da, İslam'ın etkisinin az ve yüzeysel olduğu konar-göçer Türk halklarının başında Kırgızların geldiği bilinmektedir. Ancak değişik bölgelerdeki Kırgız boylarının aralarında bu açıdan önemli farklılıklar bulunmaktadır. XIX. yüzyılın ikinci yarısından XX. yüzyıl başlarına kadar tarihçi, etnograf ve seyyahların Kırgızların İslami hayatı hakkında verdikleri bilgiler bunu doğrulamaktadır (Erşahin, 1999a: 427).

Rus subayı Mikhail Ivanovich Venyukov, 1865 yılında yaptığı gözlemlere dayanarak Çin sınırında, Tanrı dağlarının eteklerindeki göçer Kırgız boylarının dinî hayatına dair genel değerlendirmeler yapmıştır:

"Kırgızların ahlaki tüm kavramları ve fikirleri en eski (ilkel) inançlar ve önyargılar üzerine kurulmuştur. Kırgızların dini İslam'dır. Bununla birlikte onların, özellikle Çin'e komşu kabilelerin arasındakilerin 
Müslümanlığı çok yüzeyseldir. Bazı Kara-Kırgızlar Allah'ın doksan dokuz ismini bilmek şöyle dursun, Peygamberlerinin ismini dahi bilmezler. Kur'an'da kesin şekilde yasak edilen sarhoşluk, Kırgızlarca bir günah olarak görülmez. Birçok başka konuda onlar cehalet yoluyla Kur'an'ın belirlediği kuralları açıçca ihlal ederler. Gariptir ki, Şamanizm'in bazı adetleri hala bu insanlar tarafından korunur" (Veniukof, 1865: 287-288).

Alman asıllı Rus Türkolog'u Radloff'un 1859-1870 yılları arasında Sibirya ve Türkistan'a yaptığı seyahatlerinde tuttuğu notlarda Kırgızların dinî hayatına dair Tatar mollalarından nakiller ve kendi gözlemleri yer almaktadır:

"Kırgızların hepsi de, Kazaklar gibi Müslüman (Busurman) dır, ancak onların İslamiyet'i daha geç kabul ettikleri söyleniyor. Tatarlar, Kırgızların tamamıla putperest olduklarını, ne oruç, ne namaz ve ne de imanın şartlarını bilmediklerini ve hatta peygamberin adından bile habersiz olduklarını iddia ederler. Fakat bana kalırsa diyebiliriz ki Kırgızlar kendilerini çok ciddi Müslüman sayar ve Kalmıkları kâfir sayarak kendilerini onlardan kesin surette ayırırlar. Din üzerine bilgileri az olmakla beraber, onlar Kazaklara nazaran daha fanatiktirler, destanları din savaşından bahseder. Bunun sebebi, kısmen belki de kâfirlere komşu olarak yaşamalarından ileri gelebilir" (Radlof, 1976: 202-203). Şehirli Tatar Müslümanlarının Kırgız göçerlerine olumsuz bakışları, Türk yurtlarında sık görülen yerleşik-göçer Müslümanlığının çatışmasını yansıtmaktadır. Aynı çatışma Anadolu'da da görülmüştür . Radloff'un kendi değerlendirmeleri ise daha sıhhatli gözlemlere dayanmaktadır.

Amerikalı diplomat Eugene Schuyler 1873'de Issık göl civarında karşılaştı̆̆ı Kırgızların dinî hayatı konusunda onları iki gruba ayırarak bilgiler vermektedir:

"Din hususunda Kazaklar gibi, Kırgızların pek azı Muhammed'in varlığını işitmiş olsa da ismen Müslümandırlar. Daha az bir kısmı da ne namazları bilir ne de bu akidenin vecibelerini yerine getirir. Yaşantılarında eski Şamanist inançların izlerini taşırlar." (Schuyler, 1877: 137-138).

Fransız Gabriel Bonvalot, 1881'de Taşkent'teki Kırgızların şehir hayatı içinde konar-göçer yapılarını muhafaza ettiklerine vurgu yaparak genel bilgiler vermektedir:

“Taşkent'te Kırgızlar Cakka-Pazar mahallesinde çoğunluktadırlar. Törelerini ve göçebe meşgalelerini muhafaza etmişlerdir; çadırda yaşarlar, at ve diğer ehli hayvanları beslerler, Sartlar için kötü kımız ve arpa ile pirinçten boza denilen hafifçe sarhoş eden mayalı bir içki imal ederler. Kırgız çok ateşli bir Müslüman olmayıp, din hususunda bir hayli ilgisizdir" (Bonvalot, 1970: 36). 
İngiliz papaz, kâşif ve yazar Henry Lansdell, 1882'de Kırgızları iki gruba ayırarak bazılarının Kur'an'a göre ibadet ettiklerini, diğerlerinin ise eski inançları ile karışık bir dinî hayatları olduğunu iddia etmektedir:

“Rus kayıtlarında Kırgızlar Müslüman ve Sünni olarak kaydedilmişlerdir. Kırgızların hepsi yüce bir yaratıcıya inanıyorlar, ama bazıları Kur'an'a göre O'na ibadet ediyorlar; diğerleri eski putperest kalıntıları İslam ile karıştırıyorlar" (Lansdell, 1885: 343-344).

Joohn Wood, dağlık Pamir bölgesindeki Kırgızların XVII. yüzyılın başlarında Şamanizm'den İslamiyet'e geçtiklerini belirterek şu değerlendirmeleri yapmaktadır:

"Onların eski inançları henüz tamamen ortadan kalkmamıştır. Pamir bölgesindeki bu Kırgızlar eski inançları için bütün din değiştirenler gibi görünmekte, yeni doktrinleri için en sefil saygı ile doludurlar" (Wood, 1872: 224).

XIX. yüzyılda Türk ve Müslüman asıllı seyyahların kaleme aldıkları eserlerde de Kırgızların Müslümanlığı ve dinî hayatları hakkında benzer tespitler görülmektedir. Mesela bölgeyi çok iyi tanıyan Kazak aristokratlarından olup, Rus tesirinde kalan, coğrafyacı ve bilim adamı Çokan Velihanov, Kırgızların Müslümanlığı hususunda şu genel değerlendirmeleri yapmıştır:

“Bütün Kırgızlar İslam'ı tutar fakat onun talimatlarını bilmeden 'Müslümanız' derler. Onların bütün inançları Orta Asyalıların eski dinî inançlarıdır. Onlar bu inançları saklamışlardır. Molla ve diğer Müslüman muallimler Kırgız halkının içinden çıkmamıştır". Bununla beraber Velihanov'un kayıtlarına göre Kırgızlar Allah ve Kduay (Farsça Huda) kelimelerini devamlı kullanmışlar ve “Kayrumdu, ırayumdu Allah'nın atınan" (Rahman ve Rahim alan Allah'ın adıyla), anlamina gelen "Bismilla"yı (Besmele'yi) her zaman dillerinden düşürmemişlerdir (Erşahin, 1999a: 428).

Velihanov, Çinliler ve Kalmukların "Burut" diye adlandırdıkları Tanrıdağı Kırgızlarını gözlemleyerek şu değerlendirmelerde de bulunmuştur: "Kırgızlar (Burutlar) kendilerine Müslüman diyorlar ama henüz Muhammed'in kim olduğunu bilmiyorlar. Onların düğün ve cenaze törenleri Şaman tarzında yapılır, ama eğer bir Tatar veya Orta Asyalı mollanın yardımını sağlayabilirlerse dualar okunur. Kendimden emin bir şekilde iddia edebilirim ki, Isık Göl'den Bedehşan'a bütün bölgenin tamamında bu kabileden okuyabilecek bir tek şahıs yoktur" (Valikhanof, 1865: 85).

Bu seyyahlardan başka Rus Levshine, Kırgızların dini konusunda onların Müslüman, putperest (pagan) veya Maniheist olup olmadıklarına 
karar vermenin zor olduğunu söyler (Lansdell, 1885: 343). F. Poryakov, 1891'de Yedi Su Kırgızlarının büyük çoğunluğunun Allah, Peygamber ve Kur'an'ı bilmediklerini belirtmektedir. A.G. Serebrennikovda, dindar Kırgız uruklarının yaşadığı Pamir bölgesinde 1902'de yaptığı tespitte İslam'ın yabancı adetler, hurafeler ve batıl itikatlar ile gölgelendiğini hatta kaybolduğunu vurgulamaktadır. V.V. Nalivkin, 1913'te Kırgızların İslam'ı neredeyse hiç bilmediklerini, şeriatı kendilerine göre yorumlayıp kolaylaştırarak yaşadıklarını, bununla beraber dine samimiyetle sarıldıklarını ve "ismen Müslüman" olduklarını kaydetmektedir (Erşahin, 1999a: 427).

1903 ve 1906 yıllarında Tanrı dağları çevresinde seyahat eden Huntington, Kırgızları yüksek yaylalarda yaşayan Müslüman göçebe bir ırk olarak tanitmaktadır (Huntington, 1907: 106).

Rickmers, Pamir bölgesindeki Kırgızların dini hakkında şu bilgileri aktarmaktadır: “İsmen Müslüman olmalarına rağmen Kırgızlar bu dinin sıkı bir takipçisi değildirler. Kadınları kapalı değildir ve ben şu ana kadar namaz kılan birisini görmedim. Ama bu onların bölgedeki, dürüst, açı sözlü, sportif ve misafirperverliklerini koruyan en sempatik irk olmalarını engellemez" (Rickmers, 1913: 382).

Bu seyahatnamelerde ayrıca Kırgızların dinî hayatlarına dair bazı ayrıntılar da yer almaktadır:

\section{a. İslam Öncesi Bazı İnançlar}

Radloff, Tatarlardan dinlediği bilgilere göre Kırgızların arasında İslam öncesi bazı inançların yaşadığını nakletmektedir: "Kırgızların arasında eski putperestliğin birçok hatıraları da yaşarmış. Bana anlattıklarına göre, mesela gerek erkek ve gerek kadınlar, ateşin üzerine yağ döker ve önünde eğilirlermiş. Bu gibi bir merasim Perşembe günleri dokuz ateş önünde yapılırmış. Erkekler, halk efsanelerine göre eskiden azizlerin yaşamış olduğu ağaçlıklar civarında lamba yakarlarmış" (Radloff, 1976: 202).

Radloff'un putperestlik döneminden kalan bir hatıra olarak değerlendirdiği ateşe yağ dökme ve önünde eğilme geleneği Kırgızların çok eski evlilik adetlerinde görülmektedir. Gelinin kayınbabasının çadırına ilk giriş merasimine otko girgizüü denilmektedir. Eskiden Kırgızlarda yeni gelini ateşe yağ döküp onun önünde eğdirerek otko girdirme geleneği vardı (Yüce ve Dosbayeva, 2007: 17). Günümüzde de gelin, damat evine gelince bir ateş yakılır, ateşin etrafında gelin ve damat üç defa dönerler. Böylece gelinin baba evinden, damadın da eski hayatından getirmiş olması mümkün olan kötülük, bela, nazar vb. maddi ve manevi kirlerden temizleneceklerine ve hayatlarında yeni ve temiz bir sayfa açacaklarına inanılır. Bu gelenek eski 
Türk inancında temizleyici ve arındırıcı fonksiyonu olan ateş kültüyle ilgilidir (Polat, 2005: 180).

Aynı konuda benzer bilgiler Rus Bardashef'de de görülmektedir: “Kara-Kırgızlar Perşembe gecesinde ateşe tapma ayinini icra ederler. İçyağı alevlerin üzerine atılır ve etrafına dokuz lamba konur. Eğer okumasını bilen birisi varsa dualar da okunur ve bu esnada ibadet edenler yere kapanırlar" (Veniukof, 1856: 288-289; Schuyler, 1877: 138).

Schuyler, Kirgızlar arasındaki kamlara dair kısa bilgiler vermektedir: "Kırgızlar yaşantılarında eski Şamanist inançların izlerini taşırlar. Şamanlar uzun saçlı olup şapka ve kuğu tüyünden kolluklar giyerler. Hatta bunlar Kazaklardan daha fazla müzik ve şiire düşkündürler" (Schuyler, 1877: 138).

\section{b. Okur Yazarlık Oranı ve Dinî Eğitim}

Atkinson, İrtiş bölgesindeki Kırgızlar arasında mollalar hariç okuma yazma bilen hiçbir kimsenin olmadığını söyler. Bu mollaların çok zengin olduğunu ve halka bir koyun karşılığında muska yazdıklarını anlatır (Atkinson, 1858: 264).

Venyukov'a göre Issık Göl'e Rusların gelmesinden önce burada öğrenmenin tek kaynağı Kur'an'ın ilk bölümünü çocuklara okumayı öğreten ama anlamını bilmeyen gezgin Taşkentlilerdi. Rus Tatarların (Kazan Tatarları) görünmesinden sonra okuyabilen ve yazabilenlerin sayısı biraz arttı. Eğitim talebi daha fazla hissedilmeye başladı. Kırgızların büyük çoğunluğu kendi aralarında eğitim imkânlarına sahip değillerdi, çocuklarını Büyük Orda'da, avullarında hemen her zaman Tatar öğretmenler bulunan arkadaşlarına gönderdiler. Ancak 1850'lerde bile bin Kırgız arasında okuyabilen ve yazabilen bir tek kişi zor bulunuyordu ve onların Manaplarının (yöneticiler) çoğu kendi halkı kadar cahildi (Veniukof, 1856: 287).

Lansdell'in verdiği bilgilere göre 1880'li yıllarda Semirec bölgesinde Kırgızlar arasında avuldan avula gezen mollalar görülmekteydi. Bu mollalar arasında Semerkant veya Buhara'da belirli bir dinî eğitim almış olanlar vardı. Lansdell, bu mollaların halkın gösterdiği hürmetten hoşnut, ama çoğunun gülünç derecede cahil ve tembel olduklarını, her şeye inanan saf bir ırkı istismar ettiklerini, bunu yaparken de akrabalık bağları ve büyücülüğe başvurduklarını iddia etmektedir (Lansdell, 1885: 346).

Konar-göçer bir hayat yaşayan Kırgızların Rus işgali öncesi okuryazarlık oranına dair yeterli bilgi bulunmamaktadır. Bilindiği gibi göçebe kültürde sözlü edebiyat gelişme göstermiştir. XIX. yüzyılın sonları ile XX. yüzyılın başında Kırgız ozanlık (akınlık) geleneğinde okuma-yazma bilen, 
kendi eserlerini yazan cazgıç akınlar (âşık, ozanlar) görülmektedir (Arvas, 2011: 29). XIX. yüzyılda güneydeki yerleşik Kırgızlar arasında faaliyet gösteren mektep ve medreseler vardı. Ancak kuzey ve doğudaki Kırgız göçerleri arasında mektep ve medreseler aracılığıyla yürütülen eğitim faaliyetleri oldukça sınırlıdı. Kuzey ve doğu bölgelerindeki göçerler arasında gezgin mollalar görülmekteydi. Rus işgaliyle birlikte ise önemli yerleşim merkezlerinde Rus-Tüzem (Rus-Yerli) mektepleri açılmıştır. Rusların 1897 yılında yaptıkları nüfus sayımında okuma-yazma oranı Kırgızlarda \% 0,6 olarak görülmektedir (Erşahin, 1999b: 80-81).

Kırgızların Rus hâkimiyeti altına alınmalarından sonra Rus iskân politikasına uygun olarak Kırgız topraklarına Rus ve diğer Slav kavimlerle birlikte Müslüman Özbekler, Uygurlar ve Tatarlar da göç edip yerleşmişlerdir. Müslüman din adamları özellikle güney bölgelerindeki Kırgızlar arasında İslami ilimleri yaymaya çalışmışlardır. XIX. yüzyılın sonu ile XX. yüzyılın başında Müslüman ilkokulları bir hayli çoğalmış, hatta bazı Kırgız zenginleri tarafından medreseler açılmıştır. Kırgız gençleri yavaş yavaş Kırgız ülkesinde Tatar, Özbek, Uygur ve Dunganların (Müslüman Çinli) kurdukları medreselerde, bazıları da bugünkü Özbekistan, Tacikistan, Doğu Türkistan (Uygur), Tataristan, Baskurdistan ve hatta Azerbaycan'daki medreselere gidip eğitim görmüşlerdir. 1900-1910 arasında Kırgızistan'ın kuzeyinde muhacir Tatarlar, güneyinde ise meskûn Özbekler Cedit mektepleri açmışlardır. XIX. yüzyılın sonu ile XX. yüzyılın başında, eski usulde eğitim veren dinî ocaklarda, yeni usule göre Türkçe eğitim veren Cedit mekteplerinde ve Rusça eğitim veren mekteplerde okuyan Kırgızların sayısı artmıştır (Koç, 2009: 23-24).

Ancak bu döneme kadar Kırgızların örf ve adetlerini, toplum hayatını ve psikolojisini bilen, kendilerinin yetiştirdiği Kırgız mollaları olmamıştır. Kırgızların kendilerinden olan din adamı konusunda büyük sıkıntı çektikleri bilinmektedir. Bu ihtiyaçlarını daha çok Uygur, Özbek ve Tatar (Kazan) mollalarla karşılamaya çalışmışlardır. Kuzey ve doğu Kırgızlarına Uygur mollalar, Tokmak Kırgızlarına Tatar mollalar ve güney Kırgızlarına Fergana'dan gelen Özbek mollalar din hizmeti vermişlerdir. Kırgızların kendi aralarından mollaların çıkmamasının sebepleri arasında bu mesleğe hor bakılması, mollalığın sadece Sartların yani yerleşik halkın işi olarak algılanması, medreselerden yoksun olmaları sayılabilir. Medreseler Kırgızların yaşadığı yerlerde ancak XIX. yüzyılın ikinci yarısından itibaren açılmaya başlamıştır. Çünkü Kırgızların çoğu bu tarihten itibaren yerleşik hayata geçmeye başlamışlardır. 1892' de bugünkü Kırgızistan topraklarında sadece yedi medrese vardı ve bunun beş tanesi güney Kırgızistan'da yer 
Sosyal Bilimler Dergisi 229

alan, Özbeklerin de yaşadığı Oş'da bulunuyordu (Erşahin, 1999a: 431-432; 1999c: 73-74).

\section{c. Ölüm, Yas ve Mezarlar}

Velihanov, Tanrı dağı Kırgızlarını (Burut) esas alarak onların dügün ve cenaze törenlerini şaman tarzında yaptıklarını, ama eğer bir Tatar veya Orta Asyalı mollanın yardımını sağlayabilirlerse dualar okuduklarını söylemektedir. (Valikhanof, 1865: 85).

Lansdell, misafir olduğu Kırgızlara ölüm sonrası hakkında ne düşündüklerini sormuştur. Kırgızlar "Tanrı Mankir denilen iyilik melekleri ve Nankir denilen kötülük melekleri yarattı. Bu iki melek insanın doğumundan itibaren görünmez bir halde onun omuzlarında otururlar. Mankir daima sağda oturur. Bunlar insanların bütün yaptıklarını görürler. Kendi kitaplarına iyi ve kötü yapılanları yazarlar. Ölüm halinde her iki kitap da Tanrı'ya verilir. Tanrı bunlara göre bir insanın iyiliğinin mi yoksa kötülüğünün mü ağır bastığına bakarak buna göre hüküm verir. Kötü olanlar ateşe gönderilir. Diğerleri de arzu edebilecekleri tüm iyiliklere sahip olacakları ruhlar dünyasında keyifli bir hayata kavuşurlar" cevabını vermişlerdir. (Lansdell, 1885: 345). İslam dininde Kiramen Kâtipleri olarak bilinen melekler ve cennet-cehennem hakkındaki bu bilgiler 1881'li yıllarda Lansdell'in muhatabı olan Kırgızların İslami bilgilerinin düzeyini göstermektedir.

Hedin, Pamir bölgesinde Kırgızların cenaze törenlerini gözlemlemiştir. Bir Kırgız öldügünde, cesedi iyice yıkanmış ve beyaz, temiz elbiseler giydirilmiştir. Sonra keten ve keçelere sarılarak mümkün olan en kısa sürede mezarına götürülmüştür. Toprak bir metre derinlikte kazılmış, mezarın dibinde bir kenar ayrıca içeriye doğru genişletilerek ceset buraya konulmuştur. Mezar toprakla doldurulmuş ve üzerine bir taş dikilmiştir. Eğer ölen bir bey ise onun mezarı dikdörtgen bir kaide üzerinde küçük bir kubbe ile işaretlenmektedir. Definden sonra kırk gün boyunca mezar yas tutanlar tarafından ziyaret edilmektedir (Hedin, 1898: 422-423). Bu bilgiler İslami geleneklere göre yapılan bir defin işlemini anlatmaktadır.

Velihanov, Kırgızların yas töreninin çok basit olduğunu, bunun bir yıl boyunca kıyafetlerin değiştirilmemesi veya yıkanmamasından ibaret olduğunu anlatmaktadır (Valikhanof, 1865: 81). Kırgızlarda erkeklerin yası kırkıncı gün tamamlanır ve sakallarını tıraş ederler. Bayanların yası ise bir yıl sonraki "yıllık" töreninde tamamlanarak kara veya mavi elbiselerini çıkarırlar. Bu törende akrabaları beyaz elbise hediye ederler. Ölünün üçü, kırkı, yıllığı aynıdır. Günümüzde de bu yas geleneği devam etmektedir 
(Polat, 2005: 237; Erdem, 2005: 297). Velikanov'un verdiği bilgiler bu gelenek ile ilgili olmalıdır.

Lansdell Kırgız mezarları hakkında da bilgiler vermektedir. Onun gördüğü yoksul Kırgızların mezarları basit, hüzünlü bir tümsekten ibaretti. Ama zenginlerin mezarı bir kubbe ile örtülerek yapılmış, duvarlar ise mazgallarla süslenmişti. Lansdell, daha önceki bazı seyyahların (Nöschel) Kırgızların ölülerini tepelere gömmeyi tercih ettiklerini ve mezarların üstüne çeşitli yiyecekler ve para bıraktıklarına dair bilgileri nakleder. Fakat kendisi yüksek yerlerde birçok mezar gördüğünü ama üzerlerinde bahsedilen şeyleri görmediğini aktarır. Bu mezarların Buryatlara ait olabileceğini söyler (Lansdell, 1885: 311). Eski çağlarda Kırgızların da mensup oldukları eski Türk dininde (Gök Tengri dini) yer-su inancı önemli bir yer tutmaktadır. Bu inançta yüksek dağlar ve pınarlar iyi ruhların makamı sayılmış, buralara saygı gösterilmiştir (Erdem, 2005: 193).

Veniukof, Kırgızların eskiden Issık Göl bölgesinde yaşamış antik bir ırktan kalan anıtlara saygı gösterdiklerini anlatmaktadır. Buna göre Tokmak yakınlarında büyük saygı gösterilen yüksek bir tuğla sütun vardı. Yaygın geleneğe göre bir Han, kızının ölümünden sonra zehirli böceklerden onun vücudunu korumak için yaptırmıştı. Kırgızlar atalarının eski kalıntılarına hala büyük saygı gösteriyorlardı. Atalarının mezarlarını kutsal sayıyorlar ve genellikle taş duvarlar ile çeviriyorlardı. Ölüye ait kalıntıları veya herhangi bir eklentiyi kaldırmak bir suç olarak kabul ediliyordu (Veniukof, 1865: 289).

Bozkır Türk kültüründe kam ve hanların cenazeleriyle ilgili bazı inanışlar yayılmış, "hanların kemiği meşum (uğursuz)" diyerek, onların ölülerinin uğursuzluk getirdiklerine inanılmıştır. Bu sebeple kam ve han cesetlerini kendi mezarlarından ayrı yerlere gömmüşlerdir (Erdem, 2005: 283). Han kızının mezarı da han ailesine ait bu inanışla ilgili olabilir.

Türklerin kadim yurtları olan Orhun bölgesi ve Kuzey-Batı Moğolistan'daki mezarlar iki gruba ayrılmaktadır: 1-Tümsek mezarları, 2Bozkır mezarları. Birinci grup mezarlara yerli halkın kullandığı tabirle kereksur, çud ve Kırgız mezarları adı verilmiştir. Bu mezarlar yüksek yerlerden ziyade, vadilere ve nehirlerin kesiştiği yerlere, yüksek kayalıkların eteklerine yapılmıştır. Genellikle mezarın orta kısmına taşların yığılması suretiyle bir tümsek yapılır. Bu tümseğin etrafı taşların yan yana dizilmesiyle bir halka ile çevrilir. Bu halkalar dört köşe veya yuvarlak olur. Bozkır mezarlarının ise etrafı dört köşe olarak, yassı taşlarla çevrilir. Bunlar daha çok yüksek bölgelerde bulunur ve yan yana görülmeleri oldukça nadirdir. Birbirlerinden ayr1 ve seyrek bir halde bulunurlar (Erdem, 2005: 284). 
Seyahatnamelerde Kirgızların topraklarında bulunan peygamber ve evliya mezarlarına dair bilgiler de görülmektedir. Hedin, 1894'de Kara kul gölü civarında Kırgızların evliya olarak kabul ettikleri Oksali'nin taştan yapılmış türbesini görmüştür. Türbenin çevresinde boynuzlar ve paçavraların bağlandığı bir sırık da bulunmaktaydı. Ayrıca Kırgızlar Pamir bölgesinde bulunan Mustağ Ata dağında Hz. Musa ve Hz. Ali'nin mezarları olduğuna inanıyorlar ve burayı kutsal bir yer olarak kabul ediyorlardı. Kırgızların inancına göre Hz. Musa'nın ruhu bu dağda bulunuyordu (Hedin, 1898: 167, 218).

\section{d. Şeriat ve Töre}

Kırgızlarda uruk aksakallarından çıkan ve oymağı biyleyen (yöneten) kişiye biy (Bey) denirdi. Biylik çoğunlukla babadan oğula, yani tevarüs yoluyla geçerdi. Biyler özellikle dinî işlere ve hukuki davalara bakarlardı ve daha çok örfe göre hüküm verirlerdi. XVII-XIX. yüzyılda biyler aynı zamanda uruk başçısı, siyasi önder ve kadı konumuna yükseldiler. Biy mahkemeleri 1918'de Sovyetler tarafından kaldırıldı (Erdem, 2005: 233; Erşahin, 1999c: 20).

Schuyler 1873'de Taşken'te Müslüman hayatı başlığında bilgi verirken Türkistan'da iki çeşit mahkemenin olduğunu; yerleşik nüfusun şeriata göre işleyen kadı mahkemeleri, Kırgızlar gibi konar-göçerlerin arasında ise eski Türk töresinin devamı olan örfi hukuka göre biylerin kurduğu mahkemeler hakkında bilgi vermektedir:

“Orta Asya'nın yerli nüfusunun bulunduğu yerlerde mahkemeler iki çeşittir. Yerleşik halkın olduğu bölgelerde kadı, yazılı hukuka yani Şeriat'a dayanan adaleti temsil eder. Kırgiz ve diğer göçebeler arasında ise sözlü gelenek ve göreneklerle adetlere göre hüküm veren biyler (beyler) vardır. Bu gelenekler yazll olmamasina ve formüle edilmemesine rağmen, yine de umumiyetle bilinirler. Milli hayatın saf ürünleri olan bu adetler yabancı bir medeniyetin tesiriyle değişmemiştir. Ancak birçok ayrıntılarda İslam hukuku öğretilerine doğrudan ters düşer. Bu örfi hukukun temel bir özelliği devlete ait ve cinayet suçları arasında fark gözetilmemesidir. Zira bir suç sadece diğgriyle olan ilişkisi sebebiyle değerlendirilir ve zarar gören taraf lehine kısas ile cezalandırllır. Biy tam manasıyla bir hakemdir. Herhangi bir formaliteye bağhl olmadan milli örf konusunda bilgi sahibidir. Bu yüzden işlemler tamamen şifahidir; kayda geçmez ve temyiz hakkı bulunmaz. Rusların bozkır idaresinde değişiklik yaptıkları zamana kadar biyler duruma göre seçilen, fakat sürekli olmayan memurlardı. Buna rağmen, tabii olarak dürüstlük ve adaleti ile öne çıkmış bir adam daha sık bu göreve çağrılacaktır. Fakat davalar genelde ilk gelene anlatilir. 
Yillar önce Issık Göl'e balık avlamaya giden bir Rus Kosak'ı bölgedeki Kırgızlar arasında öyle bir şöhret kazanmıştır ki sık sık kendisine biy olup olmadığ sorulmuş ve her zamanki ücret ödenmiştir. Hatta birçok mesele onun yıllar sonraki ziyaretine kadar kasıtlı olarak ertelenmiştir.

Ruslar bu kurumda Rus tesirinin yayılmasını engelleyecek hiçbir şey olmadığına inanarak biy mahkemesini korumuşlardır. Fakat bazı değişiklikler yaparak biyleri halk tarafından seçilmiş kahıcı memur yaptılar. Ayrıca bir tek biyden, biyler heyetine, oradan da Rus mahkemelerine temyiz mahkemeleri tesis etmişlerdir. Hukuk ilkelerine göre hakemlik müessesesine aykırı olan temyiz mahkemesine gitmek için yargılama ve mahkeme işlemlerinin yazılı kanunları gereklidir. Kırgızlar genelde eğitimsiz olduklarn için etkilerinin zararl olduğu yeni yeni belli olan Tatar mollaları başta olmak üzere, din adamları ve evrakları kopya edenlerin ellerine terk edilmişlerdi (Schuyler, 1877: 166-167).

Lansdell, Rus yönetiminde biylerin yargıç olarak kabul edildiklerini ve halk tarafından seçildiklerini, ancak onların zayıf ve yolsuzluğa açık yargıçlar olduğunu söyler. Ayrıca ne Rusların ne de kendi insanlarının onlara güvenmediğini ileri sürer (Lansdell, 1885: 310).

Rusya'nın Kırgız topraklarını işgal etmesi 1852 yılında başlamıştır. Ruslar ilk önce kuzey bölgelerini ele geçirmişler, 1876'da Kırgızistan'ın güney kısmı da Rusların idaresine girmiştir. Çarlık Rusya'sı sömürge altındaki toprakların idaresi için ayrı ayrı askeri nitelikli kanunlar çıartmıştır. Bu sistemde uzun süre askeri yöneticiler vazife görmüştür. Ayrıca bölgeye gelen Rus göçmenler arasından seçilen veya Rusya' dan gelen sivil idareciler de yönetimde görev almışlardır. Ancak sistemlerini kurduktan sonra kendilerine hizmet edebilecek bazı yerli idarecilere vazife vermişlerdir. 1891 yılından itibaren Kırgız soylularının (Manaplar) yönetim hakkını ellerinden almışlardır. Aynı kanunlarla Kırgız topraklarını devletleştirmişler ve buralara Rus göçmenlerini yerleştirmeye başlamışlardır. Ruslar aldıkları bu idari tedbirlerin yanı sıra Kırgızları itaat altına almak amacıyla etkili bir ceza sistemi oluşturmuşlardır (Kara, 2007: 331-333). Schuyler'in verdiği bilgilerde de görüldüğü gibi bu sistemde biyleri kullanarak bölgedeki Kırgızların yönetime itaat etmesini sağlamaya çalışmışlardır. Daha önce de belirtildiği gibi 1918 yılında da artık ihtiyaçları kalmadığından biy mahkemelerine son vermişlerdir.

\section{e. İbadetler ve Kutsal Yerler}

Rickmers, Pamir bölgesindeki Kırgızların kadınlarının kapalı olmadığını ve kendisinin şu ana kadar namaz kılan birisini görmediğini söylemektedir (Rickmers, 1913: 382). Rickmers, Pamir'de başka bir Kırgız avulu hakkında bilgi verirken ise kadınların kırmızı elbise giydiklerini ve 
beyaz örtü ile başlarını örtüklerini aktarmaktadır (Rickmers, 1913: 360). Rickmers'in kadınların kapalı olmamasından kastı Kırgız kadınlarının yüzlerini örtmemeleridir. Graham, Kırgız kadınlarının yüzlerinde peçe olmadığını, başlarını beyaz bir örtüyle örtüklerini anlatmaktadır (Graham, 1916: 168). Nitekim, R. Cobbold Pamir'de Kırgız kadınlarının diğer ülkelerdeki Müslüman kadınlara göre daha fazla özgürlüğe sahip olduklarını ve her zaman obalarına gelen ziyaretçilerle konuştuklarını belirtmektedir (Cobbold, 1900: 49).

Lansdell, Kırgızların çok az olan dinî bilgilerinin Mollalar tarafından canlı tutulduğunu söyler. Bu mollalar avuldan avula giderek cenazelerin defnine ve evlilik merasimlerine yardımcı oluyorlardı (Lansdell, 1885: 346).

Hedin, 1894'de Pamir Kırgızlarında bir çocuk doğduğu zaman akrabalarının tebrik etmeye geldiklerini, bir koyun kesilerek ziyafet verildiğini ve dualar edildiğini anlatmaktadır. Üçüncü gün molla bir kitaba bakarak çocuğa ismini vermiş, daha sonra bu isme çocuğun babasının ismi ve "oğlu" kelimesi eklenmiştir. Nikâh töreninde ise molla gelerek damat ve geline görevlerini okumaktadır (Hedin, 1898: 419-420).

Lansdell, Semireç bölgesindeki seyahati sırasında misafir olduğu Kırgız avulunda hoca denilen, halk üzerinde politik etkisi güçlü olan ve Mekke'ye giderek hacı olmuş Nogay Biy'den bahseder (Lansdell, 1885: 346). Hacca giden bu Kırgız'ın yönetici ve varlıklı sınıftan bir bey (biy) olduğu isminden anlaşılmaktadır.

Hedin, kendisine rehberlik eden Fergana bölgesinden Kırgızların Pamir'de bir koyunu keserlerken tekbir getirerek besmele çektiklerini anlatmaktadır. Yine misafir olduğu Pamir Kırgız obasında yemeklerden önce ve sonra eller yıkanmış, yemek sonrası hep birlikte "Allahu ekber" denilerek eller yüze sürülmüştür. Ayrıca bu ifade -ezan- namaz vakitlerinde her avulun yaşlıları tarafından okunmaktadır (Hedin, 1898: 224, 424).

Kırgızlar eski Türk dininde önemli bir yer tutan yer-su inancının ve İslamiyet'in etkisiyle bazı yerlere ve bölgelere kutsiyet atfetmişlerdir (Erdem, 2005: 210). Radloff, Kırgızların Isık Göl ve Narin çevresindeki kuzey Kırgız boylarından olan Bugu boyu arasında öğrendiklerine göre o civarda Kırgızlarca kutsal sayılan üç yerin olduğunu nakleder. Bunların isimleri, Şu (Çu) membaindaki Küngraman dağı, Koy-su nehri boyundaki Çulpasa dağ ve Tes boyundaki Ala-Başı-Ata dağıdır (Radlof, 1976: 202).

\section{f. Alkollü İçecekler}

Velikanof, Kırgızların kımızdan damıtılarak elde edilen alkollü bir içki içtiklerini ve bununla kendilerini her fırsatta sarhoş ettiklerini söyler (Valikhanof, 1865: 86). 
Radloff, Kırgızların keyif veren içkileri her şeyden fazla sevdiklerini ve zil zurna sarhoş oluncaya kadar içmeyi günah saymadıklarını dinlediği Tatarlardan nakletmektedir (Radlof, 1976: 202).

Bonvalot, Taşkent'te Kırgızların törelerini ve göçebe meşgalelerini muhafaza ettiklerini; çadırda yaşadıklarını, at ve diğer ehli hayvanlar beslediklerini, Sartlar için kötü kımız ve arpa ile pirinçten boza denilen hafifçe sarhoş eden mayalı bir içki imal ettiklerini anlatmaktadır (Bonvalot, 1970: 36). Kımız konar-göçer Türk halklarının beslenme kültüründe önemli bir yere sahiptir. Kırgızların dinî hayatına dair değerlendirmelerde kımız ve boza gibi sarhoş edici içecekler seyyahların en sık vurguladıkları husustur.

\section{Sonuç}

Kırgızların dinî hayatını değerlendirirken onların farklı boylarının farklı coğrafyadaki şartlarının göz önünde tutulması gerekmektedir. Genel olarak Kırgız yurdunun kuzey bölgesi ve Pamir gibi yüksek bölgelerdeki Kırgızların İslami eğitim ve kültürden daha uzak kaldığı söylenebilir. Güney bölgelerindekiler ise bu konuda daha şanslı olmakla birlikte, bütün Kırgızlar arasında göçebe hayat şartları, İslami eğitim ve bilgiden uzak olma gibi sebeplerle onların İslam öncesi gelenek ve inançları canlı kalmış, İslam dini ise yüzeysel bir şekilde benimsenmiştir.

Kırgızların dinî hayatına dair seyyahların gözlem ve değerlendirmeleri incelendiğinde, bazılarının bu konuda Kırgızları iki gruba ayırdıkları görülmektedir. Onlara göre Kırgızlar arasında azınlıkta olan grup İslami esasları ve ibadetleri az-çok bilen ve bu esaslara uymaya çalışan kesimdir. Büyük çoğunluğu oluşturan diğer grup ise sadece ismen Müslüman olan Kırgızlardır. Kırgızlara dair genel olarak seyyahların bazı ortak vurguları görülmektedir. Bunlara göre Kırgızlar kendilerini Müslüman olarak ifade etmektedirler. Özellikle putperest Kalmuklarla yaptıkları mücadeleler onların dinî duygularını güçlendirmiştir. Bu sebeple destanlarında (Manas destanı) görüldüğ̈̈ gibi din hususunda fanatiktirler. Ancak Müslümanlıkları çok sathidir. Temel dinî bilgilerden ve ibadetlerden yoksundurlar. İslam'ın haram kıldığı davranışlardan en çok vurgulananı başta kımız ve diğer içecekler ile sarhoş olmaları ve bunu bir günah olarak görmemeleridir. $\mathrm{Bu}$ da at sürülerine sahip göçer Kırgızların besin kültüründe önemli bir yer tutan kımızın sadece alkollü bir içecek olarak değerlendirilmesiyle alakalıdır. Eski inançlarını büyük oranda İslam dini altında yaşamaya devam ettikleri görülmektedir. Bu eski inançlar özellikle düğün ve cenaze törenlerinde ağırlık kazanmaktadır. Seyyahların hatalı olarak sadece Şamanizm'e bağladıkları bu inançlar eski Türk dinin esasını oluşturan Gök Tanrı, yer-su ve atalar kültüne dayanan inanç sistemidir. 
Aralarında okur-yazar veya din bilgisi olan mollaları bulunmamaktadır. Ancak Tatar (Özbek veya Kazan Tatarı) bir molla bulabilirlerse bu törenlerde bazı dualar okutmaktadırlar. Konar-göçer Kırgızlar töre ve yasa dedikleri geleneksel Türk töresini de yaşatmışlardır. Tarihi bilgilerle de örtüşen bu değerlendirmeler genel olarak halk İslam'ına mensup konargöçer Türk halklarında görülen ortak noktalardır.

XIX. yüzyıl ve XX. yüzyılın başlarında özellikle kuzey ve doğu bölgelerindeki göçer Kırgızlar arasında İslami hayatın zayıf olduğu aşikârdır. Bunun sebepleri Kırgızların yeterli düzeyde İslami bilgiye ulaşamamaları, örf ve adetlerini, toplum hayatını ve psikolojisini bilen Kırgız mollalarının olmamasıdır. Bu nedenlerle örf, adet ve destanlar Kırgızların siyasi, sosyal ve dinî hayatlarının şekillenmesinde çok daha etkili olmuştur. Nitekim günümüzde dahi Kırgızlar arasında eski Türk dininin izleri hâlâ devam etmektedir. Dinî ihtiyaçlarını daha çok gezgin Uygur, Özbek ve Tatar mollalarla karşılamaya çalışmışlardır. Kırgızlar XIX. yüzyılda ihtiyaç duydukları mollaların yetişeceği medreselerden de yoksun kalmışlardır. Bununla birlikte az sayıdaki zengin ve soylu aileler başta olmak üzere bazı Kırgızlar ücretle tuttukları mollalar vasıtasıyla çocuklarını kendi evlerinde veya çadırlarında eğitme imkânı bulabilmişlerdir. Medreseler Kırgızların yaşadığı yerlerde ancak XIX. yüzyılın sonlarına doğru açılmaya başlamıştır. Çünkü Kırgızların çoğu bu dönemden itibaren yerleşik hayata geçmeye başlamışlardır.

\section{Kaynakça}

ARVAS, Abdulselam (2011). "Günümüz Kırgız Akınları Hakkında”, Turkish Studies, Volume 6/4, (Fall 2011), 27-37.

ATKINSON, Thomas Witlam (1858). Oriental and Western Siberia, New York: Harper\&Brothers, Publishers.

BONVALOT, Gabriel (1970). Esir Yurt Orta Asya'dan, (Çeviren: M. Reşat Uzmen), İstanbul: Tercüman Yayınları.

BOZBEY, İzzet Ahmet (2011). “Quo Vadis Kırgızistan?: Sovyet Sonrası Kırgızistan'da İslami Hareketler", Orta Asya ve Kafkasya Araştırmaları, C. 6, S.11, 18-50.

COBBOLD, Ralph P. (1900). Innermost Asia, London: William Heinemann.

ERDEM, Mustafa (2005). Kırgız Türkleri Dinî ve Sosyal Hayat, Ankara: Türkiye Diyanet Vakfı Yayınları.

ERŞAHIN, Seyfettin (1999a). “Kırgızların İslamlaşması Üzerine Bazı Mülahazalar", Ankara Üniversitesi İlahiyat Fakültesi Dergisi, C. 39, S.1, 393-438. 
(1999b). Türkistan'da İslam ve Müslümanlar: Sovyet Dönemi, Ankara: İlahiyat Vakfı Yayınları. (1999c). Kırgizlar ve İslamiyet, Ankara: Sek Yayınları.

FELL, E. Nelson (1916). Russian and Nomad, London: Duckworth\&Co.

GRAHAM, Stephen (1916). Through Russian Central Asia, London: Cassel and Company.

HEDIN, Sven (1898). Through Asia, Vol. I, London: Methuen\&Co.

HUNTINGTON, Ellsworth (1907). The Pulse of Asia, New York: Houghton, Mifflin and Company.

JUSUBALIEVV, Ali (2007). Kırgızlarm İslamiyeti Kabulü, Ankara Üniversitesi Sosyal Bilimler Enstitüsü, Ankara: (Yayınlanmamış Doktora Tezi).

KARA, Füsun (2007). “Rusya'nın Kırgızistan'daki Koloni Siyaseti (18521917)", Firat Üniversitesi Sosyal Bilimler Dergisi, C. 17, S. 2, 329-340.

KOÇ, Saadettin (2009). "Sovyet Döneminden Önce Kırgız Edebiyatı”, Uşak Üniversitesi Sosyal Bilimler Dergisi, C. 2, S. 2, 22-36.

LANSDELL, Henry (1885). Russian Central Asia, Vol. I, London: Sampson Low, Marston, Searle and Rivington.

OCAK, Ahmet Yaşar (2002). Türk Sufiliğine Bakışlar, İstanbul: İletişim Yayınları. (2011). Babaîler İsyanı, İstanbul: Dergâh Yayınları.

POLAT, Kemal (2005). Beşikten Mezara Kırgız Türkleri'nde Gelenek ve İnanışlar, Ankara: Türkiye Diyanet Vakfı Yayınları.

RADLOF, W. (1976). Sibirya'dan (Seçmeler), (Çeviren: Ahmet Temir), İstanbul: Kültür Bakanlığı Yayınları.

RICKMERS, W. Rickmer (1913). The Duab of Turkestan, A Physiographic Sketch and Account of Some Travels, Cambridge: Cambridge University Press.

SCHUYLER, Eugene (1877). Turkistan, Vol. II, New York: Scribner, Armstrong\&Co.

VALIKHANOF, Captain (1865). "Travels in Dzungaria", The Russians In Central Asia, (Translated from the Russian: John and Robert Michell), London: Edward Stanford, s. 71-108.

VENIUKOF, M. (1865). “Trans-Ili and Chu Districts, Almaty, or Vernoe”, The Russians In Central Asia, (Translated from the Russian: John and Robert Michell), London: Edward Stanford, s. 239-291.

WOOD, Captain John (1872). A Journey to the Source of The River Oxus, London: John Murray.

YÜCE, Mehmet-Bibigül Dosbayeva (2007). “Kırgız Türklerinde Evlenme Geleneği", Modern Türklük Araştırmaları Dergisi, C.4, S.1, (Mart), 7-24. 


\section{EKLER:}

Ek 1: Tarih Öncesi taş abide ve Kırgız mezarları

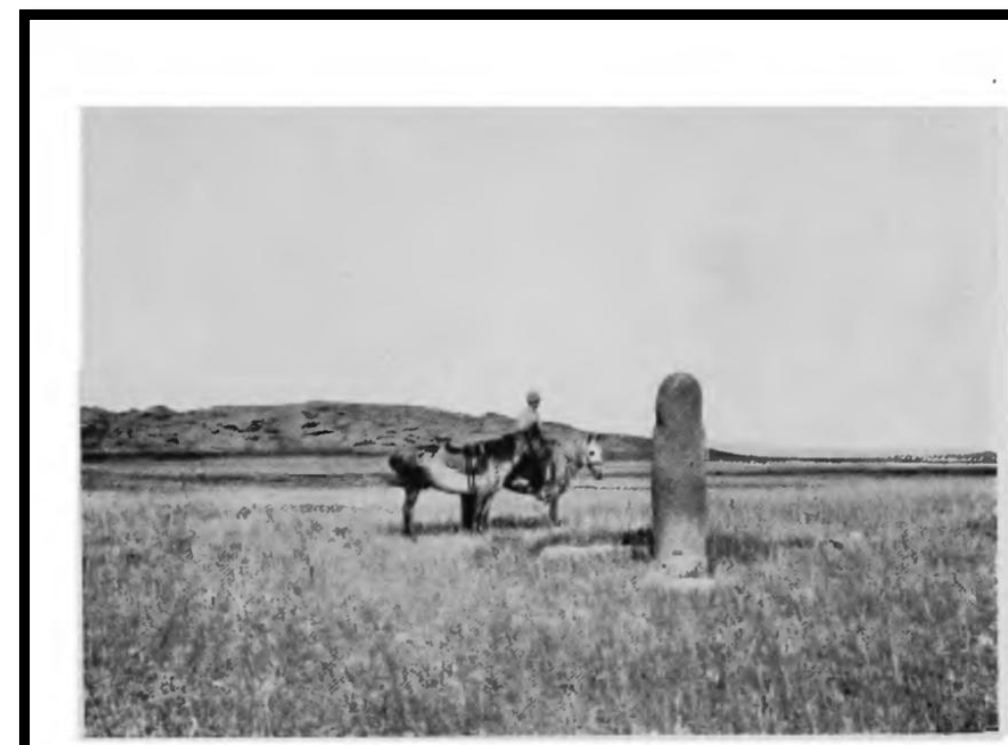

A PREHISTORIC MONUMENT OF STONE

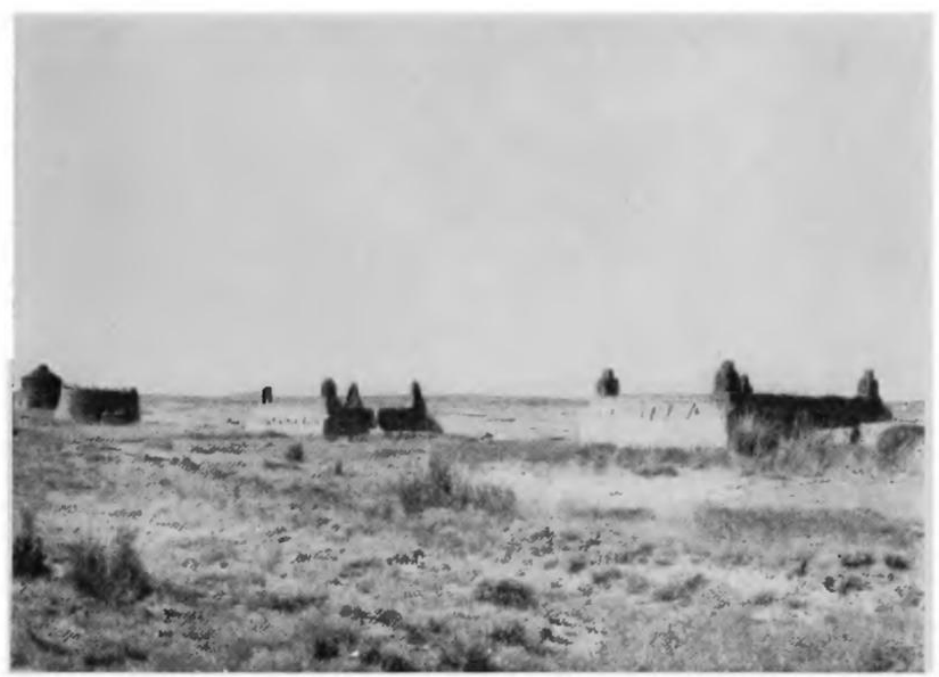

KIRGHIZ MOGHILAS, OR TOMBS

For the poor man, simple walls

Fell, E. Nelson (1916). Russian and Nomad, London, s.10. 


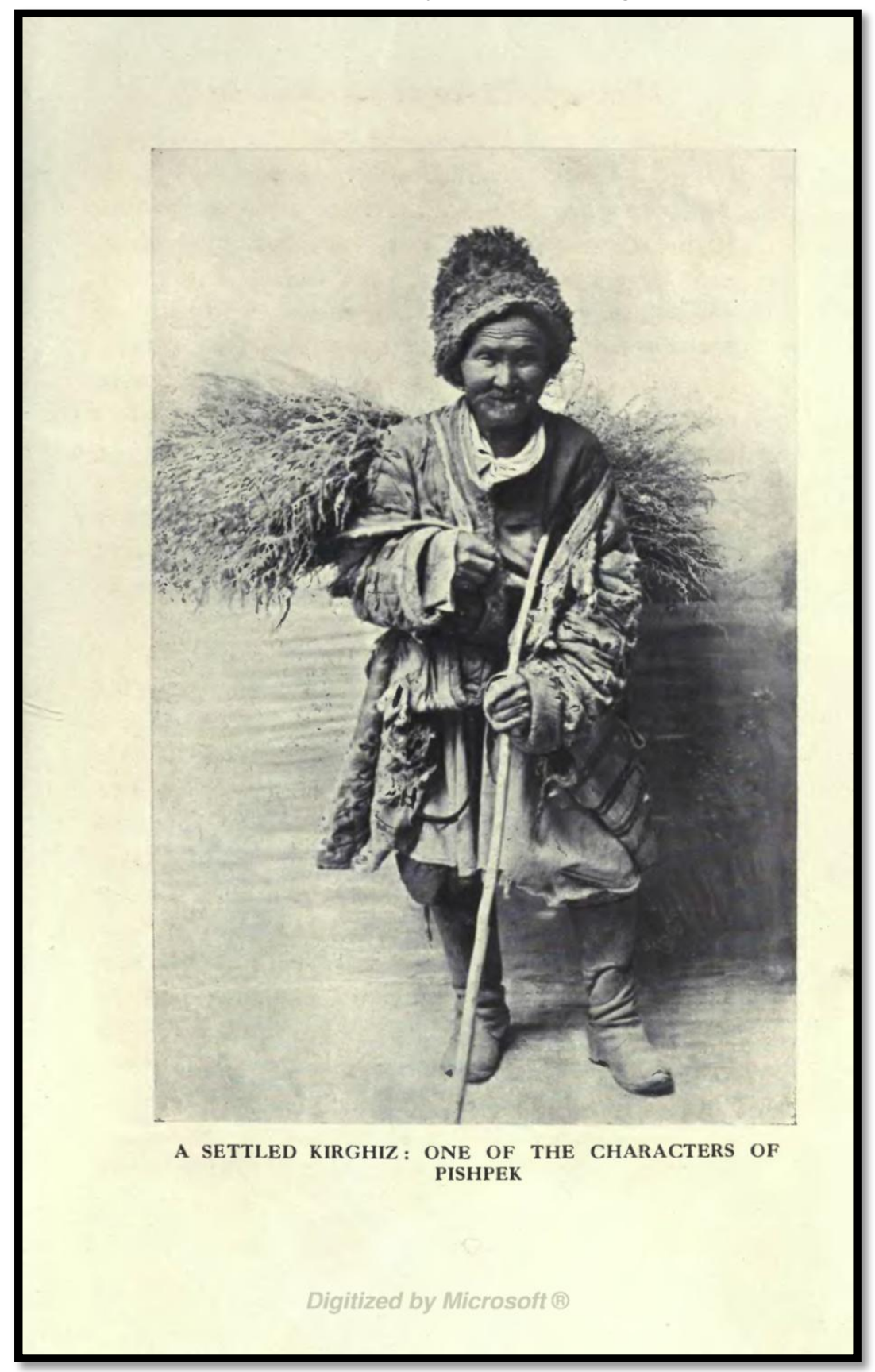

GRAHAM, Stephen (1916). Through Russian Central Asia, London, s.130. 